\title{
28 Research Square \\ Do ACE and ACE2 Polymorphisms Influence in the Pathogenesis of Diabetic Nephropathy?
}

\section{Angela Adamski da Silva Reis ( $\square$ angeladamski@gmail.com )}

Universidade Federal de Goias - Campus Samambaia https://orcid.org/0000-0002-8281-7334

\section{Elisângela Gomes da Silva}

Universidade Federal de Goias - Campus Samambaia

\section{Kamilla de Faria Santos}

Universidade Federal de Goias - Campus Samambaia

\section{Laura Raniere Borges dos Anjos}

Universidade Federal de Goias - Campus Samambaia

\section{Rodrigo da Silva Santos}

Universidade Federal de Goias - Campus Samambaia

\section{André Henrique Freiria-Oliveira}

Universidade Federal de Goias - Campus Samambaia

\section{Research Article}

Keywords: Diabetes, genetic polymorphism, genetic susceptibility, ACE gene, ACE2 gene

Posted Date: September 30th, 2021

DOI: https://doi.org/10.21203/rs.3.rs-936006/v1

License: (c) (i) This work is licensed under a Creative Commons Attribution 4.0 International License.

Read Full License 


\section{Abstract}

\section{Background}

In this study, we reported the impact of polymorphisms in the ACE and ACE2 encoding genes on diabetic nephropathy (DN) susceptibility in Brazilian subjects from the Goiânia region of central Brazil. These genes have been increasingly highlighted, mainly due to their relationship with the severity of COVID-19.

Methods and Results

In this study, 196 diabetic individuals (101 patients with DN and 95 without DN) were investigated. Genotyping of the ACE gene was performed by real-time PCR, and ACE2 gene analysis was conducted through PCR/RFLP. Our results indicate that the I/D genotype presented increased risk in the development of $D N(O R=2.5 ; p=0.01)$. This finding shows the $D$ allele influences the circulating levels of angiotensin II and, as a consequence, arterial pressure increases, the glomeruli will be affected, culminating in glomerular damage and, consequently, DN. By combining ACE and ACE2 genotypes, we observed an evident risk tendency $(\mathrm{OR}=2.51 ; \mathrm{p}=0.07)$ associated with the combination of $A C E(\mathrm{I} / \mathrm{D}$ or $\mathrm{D} / \mathrm{D})$ and wild type ACE2 (GG) polymorphisms, as well as for the combination of the same polymorphism and ACE2 heterozygous or mutant ( $G A$ or $A A$ or $A)(O R=2.61 ; p=0.08)$.

\section{Conclusions}

Our findings suggest that $A C E$ polymorphism could have an important role in the DN pathogenesis, as well as in the variations of the clinical parameters investigated in this research. However, ACE2 polymorphism was not correlated with DN. Thus, characterization of $A C E$ and ACE2 polymorphisms in patients with Diabetes Mellitus need more studies for appropriate and effective clinical conducts based in genotype.

\section{Introduction}

Diabetic nephropathy (DN) is the leading cause of end-stage renal disease worldwide, and approximately $30 \%$ of type 2 diabetic (T2DM) patients develop DN irrespective of glycemic control [1]. DN is characterized by proteinuria as result of glomerular lesions triggered by high intraglomerular pressure. In consequence, there is a decrease in the glomerular filtration rate (GFR) that often leads to renal failure, which might require renal dialysis or kidney transplantation for the patient [2].

A significant proportion of patients with Diabetes Mellitus (DM) do not develop DN despite long-standing severe hyperglycemia whereas others develop the disease even under intensive insulin therapy. This indicates that factors other than chronic hyperglycemia may also contribute to the susceptibility to the development of DN. Although the exact causes of DN are not fully known, it has been suggested that genetic factors influence in the pathogenesis of DN $[3,4]$. 
Numerous factors may predispose the diabetic patients to DN, such as those that compromise ReninAngiotensin-Aldosterone System (RAAS) [5]. RAAS is an endocrine axis with a critical function in the maintenance of hemodynamic stability through the regulation of glucose metabolism, electrolytes, blood pressure, and fluid homeostasis. Studies indicate that the genes involved in this system are highly polymorphic and the majority of the DNA variants result in an inefficient regulation of hemodynamic stability $[5,6]$. The DM patient exhibits chronic hyperglycemia that is linked to altered blood pressure levels, which negatively impairs the nephrons. Thus, disfunction of the juxtaglomerular apparatus caused by sclerosis could result in microvascular complications such as $\mathrm{DN}[6,7]$.

Among the polymorphisms associated with RAAS, we highlight those in the genes encoding the angiotensin I conversion enzyme (ACE) and its homologous enzyme (ACE2) [8, 9]. The ACE gene polymorphisms include several single nucleotide polymorphisms (SNPs), and only 34 of which are located in the coding regions [8]. The most prominent polymorphism of ACE gene is the insertion (I)/deletion (D) polymorphism. Characterized by the presence or absence of a $287 \mathrm{bp}$ fragment in intron 16 of the gene, this polymorphism has been associated with increased (allele D) and decreased (allele I) enzyme activity, respectively $[5,8,9]$.

Moreover, there is other polymorphism of interest in the association with secondary complications of DM. The SNP G8790A (rs2285666) in the gene encoding ACE2 enzyme has attracted considerable attention from the scientific community. ACE2 gene is located in the Xp22.2 chromosome in a non-inactivated region that leads to the phenotypical differences between males and females and tissue-specific gene expression $[10,11]$. This gene has been associated in some studies with cardiovascular and renal pathologies. In these investigations, the expression of the ACE2 gene is altered in both the kidney of mice diabetic model and in human renal disease [11-14]. ACE2 gene polymorphisms result in the reduction of its expression which, hypothetically, may influence the occurrence of DN [11].

Despite the few studies involving the polymorphisms cited, especially in the population of Central Brazil, the objective of this case-control study was to characterize the polymorphisms in ACE and ACE2 genes and to verify their possibility of association with DN in T2DM) patients.

\section{Methods}

\subsection{Declaration of Ethics}

This research was approved by the Research Ethics Committee of the Federal University of Goiás (UFG), Brazil, under the protocol number $195 / 11$ on June 27,2011 . This study was conducted following the Ethical Principles for Medical Research Involving Human Subjects of World Medical Association (WMA) and the Declaration of Helsinki.

\subsection{Subjects}


In our study, we included 101 DM patients with DN in hemodialysis in the Hemodialysis Unit of the Clinical Hospital-UFG, NefroClínica and São Bernardo Hemodialysis Clinics in Goiânia city, state of Goiás. Our control group was composed of 95 patients with DM without DN that were monitored by the Endocrinology Service of the Clinical Hospital of the Federal University of Goiás (UFG). Detailed clinical data of each patient were acquired from medical records.

An Informed Consent Form was signed by each participant after a brief description of the purpose and design of this research. Data about life, occupational history, smoking history, alcohol addiction, general health conditions, previous diseases, and other anamnesis were obtained during interviews with the patients. Only patients who had smoked for at least one year before the DM diagnostic were considered as smokers. For alcohol consumption, some individuals reported drinking only occasionally or socially. At the end of the interviews, we collected $5 \mathrm{ml}$ of peripheral blood from all participants.

\subsection{ACE and ACE2 polymorphisms genotyping}

Peripheral blood samples were collected in heparinized tubes and stored at $-20^{\circ} \mathrm{C}$. The DNA was extracted using the DNA PureLink ${ }^{\circledR}$ Genomic DNA Mini Kit (Invitrogen by Life Technologies, CA, USA). To determine $A C E$ polymorphism, the Insertion $(65 \mathrm{pb})$ and the Deletion (84 pb) alleles were analyzed by qPCR Real Time (SYBR Green) assay followed by obtaining the melting curve. The primers and the thermocycling conditions were applied as previously described [15].

For ACE2 analysis, we determined the genotypes by the PCR-Restriction Fragment Length Polymorphism (PCR-RFLP). The primers used and the PCR thermocycling conditions applied in this method were previously described [16]. The product of the PCR was submitted to the enzymatic digestion by the enzyme Alu I. The visualization of the RFLP products were executed in $8 \%$ polyacrylamide gel colored in a $4 \mathrm{~g} / \mathrm{L}$ silver nitrate solution.

Genotypes were identified by the size of the fragments. Homozygous mutant individuals for the polymorphism (A/A) showed two fragments of DNA (281 pb and $185 \mathrm{pb}$ ). In addition, the homozygous wild-type individuals $(G / G)$ presented one fragment of DNA with $466 \mathrm{pb}$. The heterozygous individuals (G/A) presented three fragments of DNA: $466 \mathrm{pb}, 281 \mathrm{pb}$, and $185 \mathrm{pb}$.

\subsection{Statistical Analysis}

The Chi-Square Test was used to compare the genotype frequencies, and the Fisher's Exact Test was applied when necessary. Allelic frequencies were tested for the Hardy-Weinberg Equilibrium Test. Multivariate Logistic Regressions were employed to evaluate the genotype and the risk allele and the susceptibility to the DN. The Multivariate Logistic Regression combined the genotype variable with the covariates gender, smoking habit, alcohol consumption and age. The T-Test Student was employed to compare the clinical variables. The GFR was estimated by the Cockfrot-Gault formula, which considers the levels of creatinine, weight, and age. The values for $p<0.05$ was considered as statistically significant. All statistical analyses were conducted using RStúdio software (v.1.0.153). 


\section{Results}

\subsection{Demographic, characteristics, clinical, and laboratory data}

In this study, 196 DM subjects, 101 DN patients (43 women and 58 men) and 95 without DN (67 women and 28 men) were investigated. An average age of $60.56 \pm 11.78$ years and $60.40 \pm 10.21$ years was observed for patients with and without DN, respectively. Our results demonstrate that men $(57.43 \%)$ presented a higher incidence of DN when compared to women. In addition, analyzes of clinical variables revealed a decrease in BMI, HbA1C, GFR and diastolic blood pressure in individuals with $D N(p<0.001)$.

In contrast, we observed that the creatinine rate was significantly increased in subjects with $D N(X=6.53$ $\pm 3.62 ; p<0.0001)$. In addition, we observed that the proportion of smokers showed a significant difference between the two groups ( $p<0.0001)$, being higher in patients without DN $(48.42 \%)$. On the other hand, a statistical trend $(p=0.07)$ was found in our analyses demonstrating that the time that patients were diagnosed as diabetic are significantly different for patients with $D N(X=16.67 \pm 9.86$ years) and without $\mathrm{DN}(\mathrm{X}=14.39 \pm 7.14$ years), respectively. These data are summarized in Table 1 .

\subsection{Genotypic distribution and $A C E$ and $A C E 2$ polymorphism association with Diabetic Nephropathy}

The distribution of $A C E$ and $A C E 2$ genotypes are shown in Table 2. In the DN group, the D/D genotype frequency in $A C E$ gene was $20.79 \%$, whereas the DM group without DN showed a D/D genotype frequency of $21.05 \%$. The I/D genotype frequency was $63.37 \%$ in the DN group and $48.42 \%$ in the DM group. As for I/I genotype, the frequencies within these groups were $15.84 \%$ and $30.53 \%$, respectively. It is inferred these groups are not homogeneous $\left(\chi^{2}=6.55 ; p=0.04\right)$ and the I/D genotype presented was associated with an increased risk $(O R=2.5 ; p=0.01)$ for $D N$ occurrence. It should be noted that in both groups, a higher frequency of heterozygous individuals was observed, DN group: I/D $=64(63.37 \%)$ and DM group, $\mathrm{l} / \mathrm{D}=46(48.42 \%)$.

Considering that $A C E 2$ gene is located on the $\mathrm{X}$ chromosome, we dichotomized our analysis by sex. The distribution of the genotypic frequency of ACE2 polymorphism in DN group revealed that $46.51 \%$ of the females presented GG genotype, 39.53\% GA genotype, and 13.96\% AA genotype. In DM group without DN, these frequencies were $56.72 \%, 40.30 \%$ and $2.98 \%$, for GG, AG and AA genotypes, respectively. The ChiSquare Test $\left(X^{2}\right)$ showed that the groups are homogeneous with each other $(p<0.09)$.

In addition, there is a greater number of wild genotypes in both groups. Comparing the genotypic frequencies in female, we found a bigger risk for the AA genotype $(O R=5.5)$. However, this risk was not statistically significant $(p=0.05)$ between $D N$ group and DM group. For the analysis of genotypic distribution in men we observed homogeneity between the groups, although the mutant allele was not associated with the risk $(\mathrm{OR}=0.9 ; \mathrm{p}=1)$ for $\mathrm{DN}$ development. 
The Hardy-Weinberg Equilibrium Test revealed that the allelic frequencies of $A C E$ are similar throughout the generations in both groups ( $D N: p=0.15, D M: p=0.98$ ). In addition, the allele $D$ of $A C E$ gene presented frequencies of $52 \%$ and $45 \%$ in DN and DM groups, respectively. For ACE2 gene, the allelic frequencies revealed similar throughout the generations in DM group $(p=0.60)$, but not for $D N$ group $(p<0.001)$. We verified for ACE2 G8790A in female, that A allele had a distribution frequency of $32 \%$ in the DN patients and $23 \%$ DM patients (Supplementary Table 1). For males, this frequency of the A allele was $32 \%$ and $23 \%$ in the patients with DN and DM subjects, respectively (Supplementary Table 1).

On the other hand, we combined the genotypes of $A C E$ and $A C E 2$ genes from all patients to determine the impact of these polymorphisms for the DN development. We found no association of these findings comparing the DN and DM patients with the combination of ACE and ACE2 genotypes, respectively. The same results were found for genotypic interaction among ACE and ACE2 polymorphism in for risk analysis for DN. In both analyses, the combination and genotypic interaction showed low risk and no significative statistical $(p>0.05)$. These analyses are described in Supplementary Tables 2 and 3$)$.

\subsection{Influence of $A C E$ and $A C E 2$ polymorphisms on clinical- laboratorial variables}

We analyzed the influence of the $A C E$ and $A C E 2$ polymorphisms on the biochemical and clinical modifications in the group of patients with DN. For ACE polymorphism, we observed a significant difference in some genotype's distribution for gender, but not for smoking and alcohol consumption. This observation suggests the presence of a heterogeneous distribution of the variables gender and homogeneous distribution on the other variables analyzed. Additionally, we observed that the D/D genotype was associated with a significant decrease when compared with the I/D genotypes in the DN patients, in systolic arterial pressure $(X=126.10 \pm 20.45 \mathrm{mmHg} ; \mathrm{p}=0.04)$ and evident trend of increase of $\operatorname{HbA1C}(X=8.8 \pm 2.51 ; p=0.07)$ indexes (Table 3$)$.

With respect to the influence of the ACE2 polymorphism in the clinical-laboratorial variables (Tables 4 and 5 ), we performed a separate analysis according to gender. We demonstrated that there were no statistically significant differences in the biochemical parameters for both males. In groups de female, the AA genotype in ACE2 is associated with decreased of glycemic rate $(X=4.39 \pm 3.70 ; p=0.003)$.

\section{Discussion}

$A C E$ and $A C E 2$ polymorphism had been studied as a putative mediator of DN, especially $A C E$ gene. In our results for demographic characteristics, clinical and laboratory data was found significant differences for some variables between the groups analyzed. Elevated creatinine rate and decreased GFR are characteristic of diabetic renal disease $[17,18]$, which is consistent with our findings. In addition, patients on dialysis have a marked decrease in GFR and high creatinine rate indicate that renal function is already compromised in about $50 \%$ of cases $[18,19]$. We also found a decrease in the BMI of individuals in the DN group. This difference can be explained by the level of metabolic decompensation in patients who had diabetes for several years and were undergoing hemodialysis $[18,20]$. 
It is also known that adult hemoglobin $(\mathrm{HbA})$ is formed by the non-enzymatic binding of $\mathrm{HbA}$ with glucose in the blood and this glycation is irreversible [21]. When glucose levels are high, the glycation process is intensified so that the $\mathrm{HbA} 1 \mathrm{C}$ ratio also increases. Considering that the diabetic patient presents with chronic hyperglycemia, then high values of $\mathrm{HbA}$ were expected in patients with $\mathrm{DN}[22,23]$. Our results revealed a decrease in HbA1C in DN group when compared to DM without DN group. However, patients with DN with $\mathrm{D} / \mathrm{D}$ genotype had higher $\mathrm{HbA} 1 \mathrm{C}$ and fasting plasma glucose compared to other genotypic profiles for $A C E$ polymorphism.

The fasting plasma glucose did not present a significant difference, remaining high in both DN and DM groups, respectively. This observation might have occurred because the patients had recently undergone the hemodialysis process. In addition, the glycation process may undergo some interference which reduces the functionality of the red blood cells. Among these interferences we can mention chronic kidney disease (CKD) and this causes a false reduction in $\mathrm{HbA1c}$ levels [23]. And the fact that the duration of diabetes, together with the uncontrolled hyperglycemia is the most important factor associated with the development of diabetic vascular complications [24].

The relationship between blood pressure and the risk and progression of DN is well established $[25,26]$. It is known that CKD is characterized by a marked decrease in renal autoregulation capacity, as already mentioned. This directly implies systemic blood pressure which, in turn, affects the glomeruli and consequently accelerates the progression of CKD. Thus, as expected, our results indicate an increase in diastolic pressure, which is in agreement with the literature [27-29].

By considering the time of development of DM, the patients from the DN group were diagnosed with DM earlier. This confirms studies carried out by Salgado et al. [30], which report that the peak incidence of DN is usually found between 10 to 20 years of disease. It was also observed that in the DN patients the number of smokers was lower than when compared to DM group $(48,42 \%)$. In addition, these diabetics smokers present a risk for the development of DN.

According to Eliimas Júnior et al. [31], smoking is a risk factor for CKD. Thus, the abandonment of smoking is one of the leading medical recommendations for diabetic patients, especially those undergoing hemodialysis treatment. Diabetic patients naturally constitute a risk group for CKD. However, smoking is a risk factor that should be modified as a strategy to prevent the progression of CKD in these patients.

When we observed the distribution of genotypes for $A C E, D$ allele is suggested as a risk factor for $D N$ development. These findings confirm the reports made in the study by Rodrigues [32] that demonstrated that D/D genotype in $A C E$ gene presented a greater decline in the GFR, the main characteristic of the patient with $D N$. It is noteworthy that our results indicate a significant difference for the increased risk $(O R=2.5, p=0.01)$ of $I / D$ genotype in the development of $D N$, due to the presence of $D$ allele. This observation contradicts an initial study by Kunz et al. [33] which failed to confirm the association between I/D polymorphism in DN patients in the Caucasian population. 
In addition, Tziastoudi et al. [34] findings showed the D allele of I/D polymorphism in ACE gene is an independent risk factor for both the onset and progression of DN. We suggest that $D$ allele influences the circulating levels of angiotensin II and, as a consequence, response to pressure increases, the glomeruli will be affected, culminating in glomerular damage and, consequently, DN [35].

In the meta-analysis by Smyth et al. [36], the authors demonstrated a significant association between I/D polymorphism in $A C E$ gene and the risk for DN development. Other studies with suggest that $A C E$ polymorphism favors the progression of renal disease, microvascular disorders and cardiovascular mortality, particularly among patients with $\mathrm{DM}[8,12,37,38]$.

In the genotypic analysis, it is also observed that in both groups, there are a higher number of heterozygotes, whereas there the number of individuals with mutant genotype for ACE is practically the same in both groups. This is partially consistent with studies by Aggarwal et al. [5] and Wyawahare et al. [8], where the population of heterozygotes was also larger than homozygotes and mutants. Moreover, our results are consistent with studies conducted in the population of Kutch origin [39]. In this population, the genotypic distribution had the same profile as the population studied in central Brazil population: most individuals were heterozygous, but in the population of Kutch were reported a substantial number of individuals with mutant genotype for $A C E$ in the DM group with DN.

It is important to highlight that the G8790A polymorphism in ACE2 gene in male, did not reveal any influence of the analyzed variables regardless of gender. The decreased in creatinine rate in female with AA genotype and declining trend this is same rate in female with GA genotype when compared to GG genotype, this may be justified by the smaller number of women with mutant genotype than with wildtype genotype. Some studies have considered males as a risk factor for DN occurrence [40,41], but not at all [42-44]. We then analyzed the phenotypic frequency distribution according to gender and our results showed no difference between any of the genotypes, probably because they had a high number of wildtype individuals in both groups.

The Hardy-Weinberg Equilibrium Test indicated that the distribution of the D allele in ACE gene had maintained the distribution ratios in the two groups. The same not occurred in the distribution of $A$ allele in $A C E 2$ gene. This equilibrium profile for $\mathrm{D}$ allele distribution differs in the literature. Parchwani et al. [39] described a trend of significance for the disproportion of $D$ allele distribution in the ACE gene in diabetic patients with and without DN. In these studies, patients with DN showed a trend towards a higher proportion of $D$ alleles in the genotypes. At this point, it should be noted that certain non-Caucasian races are at higher risk of developing DN [36]. However, this information is still controversial in the literature.

By combining ACE and ACE2 genotypes, we observed an evident risk tendency (OR: 2.51, $p=0.07$ ) associated with the combination of the $A C E(\mathrm{I} / \mathrm{D}$ or $\mathrm{D} / \mathrm{D})$ and wild type $A C E(\mathrm{GG})$ polymorphisms, as well as for the combination of the same polymorphism and ACE2 heterozygous or mutant (GA or AA or A) (OR $=2.61, p=0.08)$. This finding confirms from the observations of Wang et al. [45], where an association between the I/D polymorphism in the ACE gene and the risk for DN development in the Asian population was found. Ahluwalia et al. [46] and Yu et al. [47] who also showed that individuals with polymorphic ACE 
gene present greater DN susceptibility. In addition, our findings do not corroborate studies conducted with the Moroccan population, which did not reveal an association between the D/D genotype and diabetic patients with and without DN [48].

Currently, polymorphisms in RAAS components have been highlighted due to their relationship with the severity of COVID-19, caused by SARS-CoV-2. ACE2 is the cellular receptor for this coronavirus, and its expression may possibly regulate an individual's susceptibility to infection. In contrast, high ACE activity would increase the risk of lung disease. Thus, the balance between the activity of the two enzymes has been evaluated in the pathogenesis and severity of COVID-19 [49].

Finally, to our knowledge, this is the first study to describe the effects of polymorphisms in ACE and ACE2 genes on DN susceptibility, especially in the central Brazilian population. Considering all these findings, we observed that the association between ACE I/D and ACE2 G8790A polymorphisms and the susceptibility to DN are still not fully elucidated. In this way, our observations in the central Brazilian population favor the understanding of this association and emphasize the real need to investigate these polymorphisms more deeply, especially in the mentioned population.

\section{Conclusion}

Our findings show an association for $A C E$ gene analysis for DN risk, but not for $A C E 2$ gene in the same population analyzed. In spite of this, the $D$ / $D$ genotype had been associated to the modification of biochemical parameters, such as plasma glucose index and $\mathrm{HbA1C}$, which leads to the development or acceleration of DN progression. Our findings may encourage new perspectives on DM prevention and treatment to prevent patients with risky genotypes. Thus, ACE polymorphism was relevant for the development of the clinical course of DN.

\section{Declarations}

\section{Acknowledgments}

We acknowledge the Goiás Research Funding Agency (FAPEG) and National Council for Scientific and Technologic Development (CNPq) for the funding provided. The authors thank the Clinics Hospital from the Federal University of Goiás (HC-UFG), NefroClínica, and São Bernardo Hemodialysis Clinics from Goiânia, Goiás, Brazil, for supplying the samples to this study.

\section{Funding:}

This study counted on the financial support of the Goiás Research Funding Agency (FAPEG) under the number 201510267000195 to A.A.S.R., Coordination for the Improvement of Higher Education Personnel to E.G.S. and the "National Counsil for Scientific and Technologic Development (CNPq) under number $448905 / 2014-0$ to A.A.S.R. 


\section{References}

1. International Diabetes Federation, IDF (2015) Diabetes Atlas. In: International Diabetes Federation, editor. International Diabetes Federation, 7: 1-163.

2. Charlton A, Garzarella J, Jandeleit-Dahm KAM, Jha JC (2021) Oxidative Stress and Inflammation in Renal and Cardiovascular Complications of Diabetes. Biology, 10:18.

3. Xue R, Gui D, Zheng L, Zhai R, Wang F, Wang N (2017) Mechanistic insight and management of diabetic nephropathy: recent progress and future perspective. J. Diabetes Res, 2017:e1839809.

4. Cole JB, Florez JC (2020) Genetics of diabetes mellitus and diabetes complications. Nat Rev Nephrol, 16(7):377-390.

5. Aggarwal N, Kare PK, Varshney P, Kalra OP, Madhu S V, Banerjee BD, et al. (2017) Role of angiotensin converting enzyme and angiotensinogen gene polymorphisms in angiotensin converting enzyme inhibitor-mediated antiproteinuric action in type 2 diabetic nephropathy patients. World $\mathrm{J}$ Diabetes, 8(3):112-119.

6. Lovshin JA, Boulet G, Lytvyn Y, Lovblom LE, Bjornstad P, Farooqi MA, et al. (2018) Renin-angiotensinaldosterone system activation in long-standing type 1 diabetes. JCI Insight, 3(1):e96968.

7. Feng Q, Liu D, Lu Y, Liu Z (2020) The interplay of Renin-Angiotensin System and Toll-Like Receptor 4 in the inflammation of Diabetic Nephropathy. J Immunol Res, 2020:6193407.

8. Wyawahare M, Neelamegam R, Vilvanathan S, Soundravally R, Das A, Adithan C (2017) Association of Angiotensin-Converting Enzyme Gene Polymorphisms and Nephropathy in Diabetic Patients at a Tertiary Care Centre in South India. Clin Med Insights Endocrinol Diabetes, 10:117955141772677.

9. Zou H, Wu G, Lv J, Xu G (2017) Relationship of angiotensin l-converting enzyme (ACE) and bradykinin B2 receptor (BDKRB2) polymorphism with diabetic nephropathy. Biochim Biophys Acta Mol Basis Dis, 1863(6):1264-1272.

10. Talebizadeh Z, Simon SD, Butler MG (2006) X chromosome gene expression in human tissues: Male and female comparisons. Genomics, 88(6):675-681.

11. Wiese 0 , Zemlin AE, Pillay TS (2020) Molecules in pathogenesis: angiotensin converting enzyme 2 (ACE2). J Clin Pathol, 0:1-6.

12. Pinheiro DS, Santos RS, Veiga Jardim PCB, Silva EG, Reis AAS, Pedrino GR, Ulhoa CJ (2019) The combination of ACE I/D and ACE2 G8790A polymorphisms revels susceptibility to hypertension: A genetic association study in Brazilian patients. PLos ONE, 14(8):e0221248.

13. Wysocki J, Ye M, Khattab AM, Fogo A, Martin A, David NV, et al. (2017) Angiotensin converting enzyme 2 amplification limited to the circulation does not protect mice from development of diabetic nephropathy. Kidney Int, 91(6):1336-1346.

14. Liu C, Li Y, Guan T, Lai Y, Shen Y, Zeyaweiding A, et al. (2018) ACE2 polymorphisms associated with cardiovascular risk in Uygurs with type 2 diabetes mellitus. Cardiovasc Diabetol, 17:127.

15. Lin $\mathrm{M}-\mathrm{H}$, Tseng $\mathrm{C}-\mathrm{H}$, Tseng $\mathrm{C}-\mathrm{C}$, Huang $\mathrm{C}-\mathrm{H}$, Chong C-K, Tseng C-P (2001) Real-time PCR for rapid genotyping of angiotensin-converting enzyme insertion/deletion polymorphism. Clin Biochem, 
34:661-666.

16. Benjafield AV, Wang WYS, Morris BJ (2004) No association of angiotensin-converting enzyme 2 gene (ACE2) polymorphisms with essential hypertension. Am J Hypertens, 17:624-628.

17. Pavkov ME, Knowler WC, Hanson RL, Williams DE, Lemley KV, Myers BD, et al. (2009) Comparison of Serum Cystatin C, Serum Creatinine, Measured GFR, and Estimated GFR to Assess the Risk of Kidney Failure in American Indians With Diabetic Nephropathy. Am J Kidney Dis, 62(1):33-41.

18. Sociedade Brasileira de Diabetes, SBD (2016) Diretrizes da Sociedade Brasileira de Diabetes (20152016). São Paulo: A.C. Farmacêutica.

19. Botev R, Mallié JP, Couchoud C, Schück O, Fauvel JP, Wetzels JFM, et al. (2009) Estimating glomerular filtration rate: Cockcroft-gault and modification of diet in renal disease formulas compared to renal inulin clearance. Clin J Am Soc Nephrol, 4(5):899-906.

20. Murussi M, Coester A, Gross JL, Silveiro SP (2003) Nefropatia diabética no diabete melito tipo 2: fatores de risco e prevenção. Arq Bras Endocrinol Metabol, 47(3):207-219.

21. Cheneke W, Suleman S, Yemane T, Abebe G (2016) Assessment of glycemic control using glycated hemoglobin among diabetic patients in Jimma University specialized hospital, Ethiopia. BMC Res Notes, 9(1):1-10.

22. Dimer FA, Berndt ACC, Piva SJ, Moresco RN (2010) Avaliação dos níveis de hemoglobina glicada em pacientes com nefropatia diabética. Rev do Inst Adolfo Lutz, 1273(2):170-174.

23. Shepard JG, Airee A, Dake AW, McFarland MS, Vora A (2015) Limitations of A1c Interpretation. South Med J, 108(12):724-729.

24. Rangel ÉB, Rodrigues CO, Sá JR (2019) Editorial Micro- and Macrovascular Complications in Diabetes Mellitus: Preclinical and Clinical Studies. J Diabetes Res, 2019:1-6.

25. Choukem SP, Dzudie A, Dehayem M, Halle MP, Doualla MS, Luma H, et al. (2012) Comparison of different blood pressure indices for the prediction of prevalent diabetic nephropathy in a subSaharan African population with type 2 diabetes. Pan Afr Med J, 11:67.

26. Alicic RZ, Rooney MT, Tuttle KR (2017) Diabetic Kidney Disease: Challenges, Progress, and Possibilities. Clin J Am Soc Nephrol, 12:2032-2045.

27. Ohno T, Kawazu S, Tomono S (1996) Association analyses of the polymorphisms of angiotensinconverting enzyme and angiotensinogen genes with diabetic nephropathy in Japanese non-insulindependent diabetics. Metabolism, 45(2):218-222.

28. Okuno S, Utsugi T, Ohno T, Ohyama Y, Uchiyama T, Tomono S, et al. (2003) Angiotensin-Converting Enzyme Gene Polymorphism as a Potent Risk Factor for Developing Microalbuminuria in Japanese Patients with Type 2 Diabetes Mellitus: A 9-Year Follow-up Study. J Int Med Res, 31:290-298.

29. Ohno Y (2016) Central blood pressure and chronic kidney disease. World J Nephrol, 5(1):90.

30. Salgado PPCA, Santos Júnior ACS, Oliveira MM, Penido MG, Santana NF, Silva ACSE (2004) Fisiopatologia da nefropatia diabética. Rev Médica Minas Gerais, 14(3):180-185. 
31. Elihimas Júnior UF, Elihimas HCS, Lemos VM, Leão MA, Sá MPBO, França EET, et al. (2014) Smoking as risk factor for chronic kidney disease: systematic review. J Bras Nefrol, 36(4):519-528.

32. Rodrigues CIS (2000) Sistema renina-angiotensina-aldosterona e nefropatias não-diabéticas. Rev Bras Hipertens, 7(3):275-281.

33. Kunz R, Bork JP, Fritsche L, Ringel J, Sharma AM (1998) Association between the angiotensinconverting enzyme-insertion/deletion polymorphism and diabetic nephropathy: a methodologic appraisal and systematic review. J Am Soc Nephrol, 9(9):1653-1663.

34. Tziastoudi M, Stefanidis I, Zintzaras E (2020) The genetic map of diabetic nephropathy: evidence from a systematic review and meta-analysis of genetic association studies. Clinical Kidney Journal, 13(5):768-781.

35. Ferreira SRG, Zanella MT (2000) Sistema renina-angiotensina-aldosterona e nefropatia diabética. Rev Bras Hipertens, 7(3):268-274.

36. Smyth LJ, Cañadas-Garre M, Cappa RC, Maxwell AP, McKnight AJ (2019) Genetic associations between genes in the renin-angiotensin-aldosterone system and renal disease: a systematic review and meta-analysis. BMJ Open, 9:e026777.

37. Luo S, Shi C, Wang F, Wu Z (2016) Association between the Angiotensin-converting enzyme (ACE) genetic polymorphism and Diabetic Retinopathy - A meta-analysis comprising 10,168 subjects. Int J Environ Res Public Health, 13(11):1142.

38. Yuan Y, Meng L, Zhou Y, Lu N (2017) Genetic polymorphism of angiotensin-converting enzyme and hypertrophic cardiomyopathy risk: A systematic review and meta-analysis. Medicine, 96(48):e8639.

39. Parchwani DN, Kesari MG, Patel DD, Patel DJ (2015) Influence of genetic variability at the ACE locus in intron 16 on Diabetic Nephropathy in T1DM patients. Indian J Physiol Pharmacol, 58(4):327-337.

40. Ravid M, Brosh D, Ravid-Safran D, Levy Z, Rachmani R (1998) Main risk factors for nephropathy in type 2 diabetes mellitus are plasma cholesterol levels, mean blood pressure, and hyperglycemia. Arch Intern Med, 158(9):998-1004.

41. Gall MA, Hougaard P, Borch-Johnsen K, Parving HH (1997) Risk Factors for development of incipient and over diabetic nephropathy in patients with non-insulin dependent diabetes mellitus: prospective, observational study. BMJ, 314(7083):783-788.

42. Murussi M, Baglio P, Gross J, Silveiro S (2002) Risk Factors for microalbuminuria and macroalbuminuria in type 2 diabetic patients: a 9-year follow-up study. Diabetes Care, 6:1101-1102.

43. Park JY, Kim HK, Chung YE, Kim SW, Hong SK, Lee KU (1997) Incidence and Determinants of microalbuminuria in Koreans with type 2 Diabetes. Diabetes Care, 21(4):530-534.

44. Nelson RG, Knowler WC, Pettitt DJ, Hanson RL, Bennett PH (1995) Incidence and determinants of elevated urinary albumin excretion in Pima indians with NIDDM. Diabetes Care, 18(2):182-187.

45. Wang F, Fang Q, Yu N, Zhao D, Zhang Y, Wang J, et al. (2011) Association between genetic polymorphism of the angiotensin-converting enzyme and diabetic nephropathy: A meta-analysis comprising 26,580 subjects. JRAAS - J Renin-Angiotensin-Aldosterone Syst, 13(1):161-174. 
46. Ahluwalia TS, Ahuja M, Rai TS, Kohli HS, Bhansali A, Sud K, et al. (2009) ACE variants interact with the RAS pathway to confer risk and protection against type 2 diabetic nephropathy. DNA Cell Biol, 28(3):141-150.

47. Yu Z-Y, Chen L-S, Zhang L-C, Zhou T-B (2012) Meta-analysis of the relationship between ACE I/D gene polymorphism and end-stage renal disease in patients with diabetic nephropathy. Nephrology, 17(5):480-487.

48. Mansouri M, Zniber A, Boualla L, Badaoui G El, Benkacem M, Rifai K, et al. (2017) Associations between Clinical Characteristics and Angiotensin- Converting Enzyme Gene Insertion/Deletion Polymorphism in Moroccan Population with Type-2 Diabetic Nephropathy. Saudi J Kidney Dis Transpl, 28(2):261-267.

49. Gómez J, Albaiceta GM, García-Clemente M, López-Larrea C, Amado-Rodríguez L, Lopez-Alonso I, et al. (2020) Angiotensin-converting enzymes (ACE, ACE2) gene variants and COVID-19 outcome. Gene, $762: 145102$.

\section{Tables}

Table 1. Demographic characteristics, clinical and laboratory data of the DN and DM groups.

\begin{tabular}{|c|c|c|c|}
\hline Variables & $\begin{array}{c}\text { DN } \\
(\mathbf{N}=101)\end{array}$ & $\begin{array}{c}\text { DM } \\
(\mathrm{N}=95)\end{array}$ & p-value \\
\hline \multicolumn{4}{|l|}{ Demographic characteristics } \\
\hline Gender & $\mathrm{n}(\%)$ & $\mathrm{n}(\%)$ & \\
\hline Male & $58(57.43)$ & $28(29.47)$ & $<0.0001^{*}$ \\
\hline Female & $43(42.57)$ & $67(70.53)$ & \\
\hline Age (years), $\bar{X}$ and $\mathrm{SD}( \pm)$ & $60.56 \pm 11.78$ & $60.4 \pm 10.21$ & 0.92 \\
\hline DM involvement time (years), $\bar{X} \pm$ & $16.67 \pm 9.86$ & $14.39 \pm 7.14$ & 0.07 \\
\hline Clinical and laboratory datas & $\bar{X}$ and $\mathrm{SD}( \pm)$ & $\bar{X}$ and $\mathrm{SD}( \pm)$ & \\
\hline $\mathrm{BMI}\left(\mathrm{kg} / \mathrm{m}^{2}\right)$ & $25.64 \pm 4.75$ & $28.90 \pm 5.69$ & $<0.0001^{*}$ \\
\hline Fasting plasma glucose $(\mathrm{mg} / \mathrm{dL})$ & $202.65 \pm 93.30$ & $185.99 \pm 76.14$ & 0.185 \\
\hline $\mathrm{HbA1C}(\%)$ & $7.64 \pm 2.11$ & $9.18 \pm 2.85$ & $<0.0001^{*}$ \\
\hline Creatinine (mg/dl) & $6.53 \pm 3.62$ & $0.95 \pm 0.28$ & $<0.0001^{*}$ \\
\hline $\mathrm{GFR}^{\mathrm{a}}(\mathrm{ml} / \mathrm{min})$ & $27.35 \pm 39.12$ & $100.30 \pm 38.98$ & $<0.0001^{*}$ \\
\hline Diastolic Arterial Pressure & $77.32 \pm 10.30$ & $84.33 \pm 11.19$ & $\begin{array}{c}<0.0001^{*} \\
0.40\end{array}$ \\
\hline $\begin{array}{l}\text { Systolic Arterial Pressure } \\
\text { Alcohol Consumption }\end{array}$ & $\begin{array}{l}134.92 \pm 21.77 \\
\mathrm{n}(\%)\end{array}$ & $\begin{array}{l}137.40 \pm 19.00 \\
\text { n (\%) }\end{array}$ & \\
\hline Positive & $15(14.85)$ & $22(23.16)$ & 0.14 \\
\hline Negative & $86(85.15)$ & $73(76.84)$ & \\
\hline Smoking Habit & $\mathrm{n}(\%)$ & $\mathrm{n}(\%)$ & \\
\hline Positive & $11(10.89)$ & $46(48.42)$ & $<0.0001^{*}$ \\
\hline Negative & $90(89.11)$ & $49(51.58)$ & \\
\hline
\end{tabular}

The data are shown as averages $\bar{X}$ and standard deviation ( \pm ). Statistical comparisons were performed through Chi-Square $\left(\chi^{2}\right)$ or T-Test Student. *Significant statistical difference $(p<0.05)$. GFR-Glomerular Filtration Rate estimated by the Cockcroff-Gault equation, BMI - body mass index, HbA1C - glycohemoglobin. 
Table 2. Distribution of the genotypic of $A C E$ and $A C E 2$ for the case and control groups and risk analysis.

\begin{tabular}{|c|c|c|c|c|c|c|c|}
\hline Genotype & DN & DM & $\chi^{2}$ & DF & p-value & OR (IC 95\%) & p-value \\
\hline$A C E$ LD & n (\%) & n (\%) & \multirow{5}{*}{6.6} & \multirow{5}{*}{2} & \multirow{5}{*}{0.04} & & \\
\hline$I / I$ & $16(15.84)$ & $29(30.53)$ & & & & 1 Reference & ----- \\
\hline$I / D$ & $64(63.37)$ & $46(48.42)$ & & & & $2.5(1.2-5.6)$ & 0.01 \\
\hline$D / D$ & $21(20.79)$ & $20(21.05)$ & & & & $1.9(0.7-4.9)$ & 0.19 \\
\hline $\begin{array}{l}\text { Total } \\
\text { ACE2 G8790A female }\end{array}$ & $101(100)$ & $95(100)$ & & & & & \\
\hline$G G$ & $20(46.51)$ & $38(56.72)$ & \multirow{4}{*}{4.9} & \multirow{4}{*}{2} & \multirow{4}{*}{0.09} & 1 Referência & -.--- \\
\hline$G A$ & $17(39.53)$ & $27(40.30)$ & & & & $1.2(0.5-2.9)$ & 0.68 \\
\hline$A A$ & $6(13.96)$ & $2(2.98)$ & & & & $5.5(0.9-61.1)$ & 0.05 \\
\hline Total & $43(100)$ & $67(100)$ & & & & & \\
\hline \multicolumn{8}{|l|}{ ACE2 G8790A male } \\
\hline$G$ & $40(68.97)$ & $19(67.86)$ & \multirow{3}{*}{$<0.001$} & \multirow{3}{*}{1} & \multirow{3}{*}{1} & 1 Reference & ----- \\
\hline$A$ & $18(31.03)$ & $9(32.14)$ & & & & $0.9(0.3-2.9)$ & 1 \\
\hline Total & $58(100)$ & $28(100)$ & & & & & \\
\hline
\end{tabular}

Statistical analysis performed through Chi-square Test $\left(\chi^{2}\right)$ and Fisher's Exact Test. *Significant difference between groups $(p<0.05)$. OR - odds ratio, $\mathrm{Cl}$ - confidence interval.

Table 3. Association between the ACE genotypes and clinical variables of DM patients with DN.

\begin{tabular}{|c|c|c|c|c|c|c|c|c|c|}
\hline Variables & $\mathbf{I} / \mathbf{I}$ & $\mathbf{I} / \mathbf{D}$ & $\mathbf{P}$ & $\bar{I} / \mathbf{I}$ & $\overline{\mathbf{D} / \mathbf{D}}$ & $\bar{P}$ & $\mathbf{I} / \mathbf{D}$ & $\bar{D} / \mathbf{D}$ & $\bar{P}$ \\
\hline \multicolumn{10}{|l|}{ Demographic characteristics } \\
\hline Gender & $\mathrm{n}=16(100 \%)$ & $\mathrm{n}-64(100 \%)$ & & $\mathrm{n}=16(100 \%)$ & $\mathrm{n}=21(100 \%)$ & & $\mathrm{n}(\%)$ & $\mathrm{n}=21(100 \%)$ & \\
\hline Male & $5(31.25)$ & $42(65.63)$ & 0.03 & $5(31.25)$ & $11(52.38)$ & 0.34 & $42(65.63)$ & $11(52.38)$ & 0.41 \\
\hline Female & $11(68.75)$ & $22(34.37)$ & & $11(68.75)$ & $10(47.62)$ & & $22(34.37)$ & $10(47.62)$ & \\
\hline $\begin{array}{l}\text { DM involvement time (years), } \bar{X} \text { and } \pm \\
\text { Clinical and Laboratory Data }\end{array}$ & $13.92(11.15)$ & $16.90(9.32)$ & 0.38 & $13.92(11.15)$ & $17.75(10.78)$ & 0.34 & $16.90(9.32)$ & $17.75(10.78)$ & 0.75 \\
\hline $\mathrm{BMI}\left(\mathrm{kg} / \mathrm{m}^{2}\right)$ & $26.58(5.80)$ & $25.18(4.43)$ & 0.38 & $26.58(5.80)$ & $26.32(4.89)$ & 0.89 & $25.18(4.43)$ & $26.32(4.89)$ & 0.35 \\
\hline Fasting plasma glucose (mg/dL) & $208.46(81.51)$ & $199.35(89.56)$ & 0.72 & $208.46(81.51)$ & $209.44(115.94)$ & 0.98 & $199.35(89.56)$ & $209.44(115.94)$ & 0.74 \\
\hline $\mathrm{HbA1C}(\%)$ & $7.51(2.14)$ & $7.36(1.92)$ & 0.83 & $7.51(2.14)$ & $8.8(2.51)$ & 0.18 & $7.36(1.92)$ & $8.8(2.51)$ & 0.07 \\
\hline Creatinine (mg/dl) & $6.94(4.09)$ & $6.47(3.25)$ & 0.68 & $6.94(4.09)$ & $6.44(4.40)$ & 0.73 & $6.47(3.25)$ & $6.44(4.40)$ & 0.98 \\
\hline GFR $(\mathrm{ml} / \mathrm{min})$ & $20.35(34.39)$ & $26.99(38.57)$ & 0.52 & $20.35(34.39)$ & $33.70(44.75)$ & 0.33 & $26.99(38.57)$ & $33.70(44.75)$ & 0.55 \\
\hline Diastolic Arterial Pressure & $78.13(9.11)$ & $77.80(10.18)$ & 0.90 & $78.13(9.11)$ & $75.24(11.67)$ & 0.40 & $77.80(10.18)$ & $75.24(11.67)$ & 0.38 \\
\hline Systolic Arterial Pressure & $136.88(20.77)$ & $137.33(21.99)$ & 0.94 & $136.88(20.77)$ & $126.10(20.45)$ & 0.13 & $137.33(21.99)$ & $126.10(20.45)$ & 0.04 \\
\hline Alcohol Consumption & $\mathrm{n}(\%)$ & $\mathrm{n}(\%)$ & & $\mathrm{n}(\%)$ & $\mathrm{n}(\%)$ & & $\mathrm{n}(\%)$ & $\mathrm{n}(\%)$ & \\
\hline Positive & $16(100)$ & $11(17.19)$ & $<0.0$ & $16(100)$ & $4(19.05)$ & $<0.001$ & $11(17.19)$ & $4(19.05)$ & 1 \\
\hline Negative & $0(0)$ & $53(82.81)$ & 01 & $0(0)$ & $17(80.95)$ & & $53(82.81)$ & $17(80.95)$ & \\
\hline Smoking Habits & n $(\%)$ & $\mathrm{n}(\%)$ & & n $(\%)$ & $\mathrm{n}(\%)$ & & $\mathrm{n}(\%)$ & $\mathrm{n}(\%)$ & \\
\hline Positive & $2(12.5)$ & $7(10.94)$ & 1 & $2(12.5)$ & $2(9.52)$ & 1 & 7 (10.94) & $2(9.52)$ & 1 \\
\hline Negative & $14(87.5)$ & $57(89.06)$ & & $14(87.5)$ & $19(90.48)$ & & $57(89.06)$ & $19(90.48)$ & \\
\hline
\end{tabular}

The data are shown as averages $(\bar{X})$ and standard deviation $( \pm)$ or the number of individuals. Statistical analysis conducted through T-Test Student or Chi-Square Test $\left(\chi^{2}\right)$. Significance level $\mathrm{p}<0.05$. GFR - Glomerular filtration rate was estimated through the Cockcroft-Gault equation. BMI - body mass index, HbA1C - glycohemoglobin.

Table 4. Association between the alleles $\mathrm{G}$ and $\mathrm{A}$ of $A C E 2$ with the clinical-laboratorial variables in male patients with DN. 


\section{Variables}

DM involvement time (years)

BMI $\left(\mathrm{kg} / \mathrm{m}^{2}\right)$

Fasting plasma glucose (mg/dL)

HbA1C (\%)

Creatinine $(\mathrm{mg} / \mathrm{dl})$

$\mathrm{GFR}^{\mathrm{a}}(\mathrm{ml} / \mathrm{min})$

Diastolic Arterial Pressure

Systolic Arterial Pressure
A

$\mathrm{n}=18$

$\mathrm{n}=\mathbf{4 0}$

$\bar{X}$ and $\mathrm{SD}( \pm)$
$\mathbf{P}$

$\bar{X}$ and $\mathrm{SD}( \pm)$

59.85 (11.94)

$58.27(9.54)$

0.60

24.75 (4.97)

$26.16(3.88)$

0.25

$185.58(93.30)$

$206.78(59.60)$

0.31

$7.21(1.81)$

7.84 (2.37)

0.38

$6.85(3.98)$

$6.79(2.63)$

0.95

18.84 (25.51)

28.93 (48.14)

0.41

$78.12(10.11)$

$76.67(9.70)$

0.60

$134.52(19.39)$

$133.61(14.73)$

0.84

Alcohol Consumption

Positive

$6(15)$

$4(22.22)$

0.77

Negative

$34(85)$

14 (77.78)

Smoking Habits

Positive

Negative
3 (16.67)

15 (83.33)

The data are shown as averages $(\bar{X})$ and standard deviation $( \pm)$ or the number of individuals. Statistical analysis conducted through T-Test Student or Chi-Square Test $\left(\chi^{2}\right)$. Significance level $\mathrm{p}<0.05$. GFR - Glomerular filtration rate was estimated through the Cockcroft-Gault equation. BMI - body mass index, HbA1C glycohemoglobin.

Table 5. Association between the genotypes of ACE2 with the clinical-laboratorial variables in female patients with DN.

\begin{tabular}{|c|c|c|c|c|c|c|c|c|c|}
\hline Variables & $\begin{array}{c}\mathbf{G G} \\
\mathbf{n = 2 0} \\
\bar{X} \text { and SD }( \pm)\end{array}$ & $\begin{array}{c}\mathbf{G A} \\
\mathbf{n = 1 7} \\
\bar{X} \text { and } \mathrm{SD}( \pm)\end{array}$ & $\mathbf{P}$ & $\begin{array}{c}\mathbf{G G} \\
\mathbf{n}=\mathbf{2 0} \\
\bar{X} \text { and } \mathrm{SD}( \pm)\end{array}$ & $\begin{array}{c}\mathbf{A A} \\
\mathbf{n}=6 \\
\bar{X} \text { and } \mathrm{SD}( \pm)\end{array}$ & $\bar{P}$ & $\begin{array}{c}\mathbf{G A} \\
\mathbf{n = 1 7} \\
\bar{X} \text { and } \mathrm{SD}( \pm)\end{array}$ & $\begin{array}{c}\mathbf{A A} \\
\mathbf{n}=\mathbf{6} \\
\bar{X} \text { and } \mathrm{SD}( \pm)\end{array}$ & $\bar{P}$ \\
\hline $\begin{array}{c}\mathrm{DM} \text { involvement time } \\
\text { (years) }\end{array}$ & $13.44(10.16)$ & $18.58(9.48)$ & 0.22 & $13.44(10.16)$ & $18.99(13.44)$ & 0.33 & $18.58(9.48)$ & $18.99(13.44)$ & 0.95 \\
\hline $\mathrm{BMI}\left(\mathrm{kg} / \mathrm{m}^{2}\right)$ & $26.36(5.35)$ & $25.91(4.15)$ & 0.81 & $26.36(5.35)$ & $26.91(6.03)$ & 0.83 & $25.91(4.15)$ & $26.91(6.03)$ & 0.64 \\
\hline $\begin{array}{l}\text { Fasting plasma glucose } \\
(\mathrm{mg} / \mathrm{dL})\end{array}$ & $221.11(91.40)$ & $212.39(99.57)$ & 0.82 & $221.11(91.40)$ & $231.75(142.74)$ & 0.86 & $212.39(99.57)$ & $231.75(142.74)$ & 0.74 \\
\hline $\mathrm{HbA1C}(\%)$ & $7.61(2.43)$ & $7.8(1.69)$ & 0.84 & $7.61(2.43)$ & $9.26(3.30)$ & 0.36 & $7.8(1.69)$ & $9.26(3.30)$ & 0.39 \\
\hline Creatinine $(\mathrm{mg} / \mathrm{dl})$ & $8.40(3.73)$ & $5.82(3.17)$ & 0.08 & $8.40(3.73)$ & $4.39(3.70)$ & 0.03 & $5.82(3.17)$ & $4.39(3.70)$ & 0.313 \\
\hline $\mathrm{GFR}^{\mathrm{a}}(\mathrm{ml} / \mathrm{min})$ & $21.14(41.67)$ & $32.59(39.21)$ & 0.48 & $21.14(41.67)$ & $53.40(55.10)$ & 0.16 & $32.59(39.21)$ & $53.40(55.10)$ & 0.30 \\
\hline Diastolic Arterial Pressure & $77.27(10.09)$ & $77.91(10.28)$ & 0.87 & $77.27(10.09)$ & $74.00(13.50)$ & 0.54 & $77.91(10.28)$ & $74.00(13.50)$ & 0.43 \\
\hline Systolic Arterial Pressure & $\begin{array}{c}139.27(24.53) \\
\mathbf{n}(\%)\end{array}$ & $\begin{array}{c}139.05(27.57) \\
\text { n }(\%)\end{array}$ & 0.98 & $\begin{array}{c}139.27(24.53) \\
\mathbf{n}(\%)\end{array}$ & $\begin{array}{c}125.00(24.61) \\
\text { n (\%) }\end{array}$ & 0.20 & $\begin{array}{c}139.05(27.57) \\
\text { n }(\%)\end{array}$ & $\begin{array}{c}125.00(24.61) \\
\mathbf{n}(\%)\end{array}$ & 0.17 \\
\hline \multicolumn{10}{|l|}{ Alcohol Consumption } \\
\hline Positive & $1(5.00)$ & $3(13.65)$ & 0.48 & $1(5.00)$ & $1(16.67)$ & 0.95 & $3(13.65)$ & $1(16.67)$ & 1 \\
\hline Negative & $19(95.00)$ & $14(82.35)$ & & $19(95.00)$ & $5(83.33)$ & & $14(82.35)$ & $5(83.33)$ & \\
\hline \multicolumn{10}{|l|}{$\underline{\text { Smoking Habits }}$} \\
\hline Positive & $1(5.00)$ & $1(5.88)$ & 1 & $1(5.00)$ & $0(0)$ & 1 & $1(5.88)$ & $0(0)$ & 1 \\
\hline Negative & $19(95.00)$ & $16(94.12)$ & & $19(95.00)$ & $6(100)$ & & $16(94.12)$ & $6(100)$ & \\
\hline
\end{tabular}

The data are shown as an average \pm standard deviation or the number of individuals. Statistical analysis conducted through T-Test or Chi-Square Test. Significance level $\mathrm{p}$ $<0.05$. GFR - Glomerular filtration rate was estimated through the Cockcroft-Gault equation. BMI - body mass index, HbA1C - glycohemoglobin. 
This is a list of supplementary files associated with this preprint. Click to download.

- SupptablesMolecularBiologyreports.docx 